\title{
Rearrangements of the tal-1 Locus as Clonal Markers for T Cell Acute Lymphoblastic Leukemia
}

\author{
Olafur G. Jonsson," Richard L. Kitchens, ${ }^{\star}$ Richard J. Baer," George R. Buchanan," and R. Graham Smith \\ Departments of ${ }^{*}$ Pediatrics, ${ }^{\ddagger}$ Internal Medicine and ${ }^{\S}$ Microbiology, University of Texas Southwestern Medical Center, Dallas, Texas 75235
}

\begin{abstract}
Normal and aberrant immune receptor gene assembly each produce site-specific DNA rearrangements in leukemic lymphoblasts. In either case, these rearrangements provide useful clonal markers for the leukemias in question. In the $t(1 ; 14)(p 34 ; q 11)$ translocation associated with $T$ cell acute lymphoblastic leukemia (T-ALL), the breakpoints on chromosome 1 interrupt the tal-1 gene. A site-specific deletion interrupts the same gene in an additional $26 \%$ of T-ALL. Thus, nearly onethird of these leukemias contain clustered rearrangements of the tal-1 locus. To test whether these rearrangements can serve as markers for residual disease, we monitored four patients with T-ALL; three of the leukemias contained a deleted ( $\mathrm{tal}^{\mathrm{d}}$ ) and one a translocated ( tal $^{t}$ ) tal-1 allele. These alleles were recognized by a sensitive amplification/hybridization assay. $t_{a l}{ }^{d}$ alleles were found in the blood of one patient during the 4th mo of treatment but not thereafter. Using a quantitative assay to measure the fraction of tal $^{d}$ alleles in DNA extracts, we estimated that this month 4 sample contained 150 tal $^{d}$ copies per $10^{6}$ genome copies. The patient with $t(1 ; 14)\left(p_{34 ; q 11)}\left(\right.\right.$ tal $\left.^{\prime}\right)$ leukemia developed a positive assay during the 20th mo of treatment. By standard criteria, all four patients remain in complete remission 11-20 mo into treatment. We conclude that tal-1 rearrangements provide useful clonal markers for $\sim 30 \%$ of T-ALLs. (J. Clin. Invest. 1991. 87:2029-2035.) Key words: minimal residual disease $\bullet$ helix-loop-helix proteins
\end{abstract}

\section{Introduction}

T cell acute lymphoblastic leukemia (T-ALL) ${ }^{1}$ comprises $\sim 15 \%$ of all cases of ALL. Features that distinguish this disease from B-lineage ALL include higher incidence in males, older mean age at diagnosis, high mean blood leukocyte count, and the frequent presence of a mediastinal mass (1-3). Although the prognosis for both children $(4,5)$ and adults $(6,7)$ has improved with increased therapeutic intensity, $\sim 40 \%$ of children and at least $60 \%$ of adults still relapse and die of drugresistant disease.

Address correspondence and reprint requests to R. Graham Smith, Department of Internal Medicine, University of Texas Southwestern Medical Center, Dallas, TX 75235-8852.

Dr. Jonsson's current address is Department of Pediatrics, St. Joseph's Hospital, Landakot, 101 Reykjavik, Iceland.

Received for publication 2 October 1990 and in revised form 9 January 1991.

1. Abbreviations used in this paper: T-ALL, T cell acute lymphoblastic leukemia; $t^{\mathrm{d}}{ }^{\mathrm{d}, \mathrm{t}}$, deleted, translocated $\mathrm{tal}$.

J. Clin. Invest.

(c) The American Society for Clinical Investigation, Inc.

0021-9738/91/06/2029/07 \$2.00

Volume 87, June 1991, 2029-2035
Because induction of complete remission is achieved in the vast majority of patients, current efforts to prevent treatment failure focus upon modifications of postremission consolidation and/or maintenance chemotherapy. Unfortunately, the disease is not detectable by routine analysis during the remission period; thus, the effect of therapy on tumor burden is difficult to assess. A sensitive clonal assay for the residual leukemic population during remission would help guide therapeutic decisions beyond the induction period.

A number of chromosomal translocations are associated with T-ALL (8-10). Theoretically, the underlying molecular rearrangements could form the basis for sensitive clonal assays for minimal residual disease, just as BCR-ABL gene fusions have served as markers in chronic myelogenous leukemia (1115). However, no single translocation is found in more than $5-10 \%$ of cases, and $20-30 \%$ of these leukemias display no karyotypic abnormalities at all (8-10). This cytogenetic heterogeneity suggests that a number of loci will need to be characterized in detail before specific molecular probes suitable for detection of occult leukemia in the majority of cases can be prepared.

We have recently isolated and sequenced the breakpoint regions derived from one recurrent cytogenetic defect in $T$ ALL, namely the $t(1 ; 14)(p 34 ; q 11)$ translocation $(16,17)$. In six cases analyzed in detail, the breakpoints on chromosome 1 clustered within a $1-\mathrm{kb}$ region. This translocation cleaves the tal-1 gene on chromosome 1 , separating its $5^{\prime}$ end from the rest of the gene, which is transposed into the T cell receptor $\alpha / \delta$ locus on chromosome 14 . The tal-1 gene potentially encodes a protein containing a helix-loop-helix domain, which is found in a growing number of highly conserved DNA binding proteins involved in the regulation of growth and development (18). Several genes in this family are known to be disrupted in subsets of ALL (19-23). Although of potential pathogenic significance, the $t(1 ; 14)(\mathrm{p} 34 ; \mathrm{q} 11)$ translocation is found in only $3 \%$ of T-ALLs (24).

To investigate the possibility of a wider role for the tal-1 gene in T-ALL, we searched for rearrangements of this gene in the blast cells from a group of 50 patients with T-ALL. These leukemias did not harbor the $t(1 ; 14)(\mathrm{p} 34 ; \mathrm{q} 11)$ translocation. Surprisingly, 13 (26\%) of these leukemias contained rearrangements at this locus, all of which were identical at the level of Southern hybridization analysis (25). Detailed analysis revealed a site-specific $\sim 90-\mathrm{kb}$ deletion on chromosome 1 , one end of which lies $\sim 1 \mathrm{~kb}$ from the clustered translocation breakpoints in the $t(1 ; 14)(p 34 ; q 11)$ cases. As demonstrated by nucleotide sequence analysis, the deletions are all remarkably site-specific, differing at their ends by only a few bases from one leukemia to another. These deletions were not found in remission peripheral blood leukocytes and therefore appear to be leukemia specific. Thus, site-specific rearrangements at the tal1 locus characterize nearly $30 \%$ of T-ALLs: $\sim 3 \%$ are due to translocation ( tal $^{\mathrm{t}}$ alleles), while $26 \%$ result from an interstitial 
deletion that is too small to be detected cytogenetically ( tal $^{\text {d }}$ alleles). These rearrangements provide the opportunity to develop sensitive clonal assays for the relevant leukemias. In this paper, we describe assays that can detect 10 rearranged tal- 1 cells in a background of $10^{6}$ normal cells. Moreover, a modification of the assay is presented which quantitates $t a l^{d}$ alleles. Using these assays, we have monitored four patients with $\mathrm{T}$ ALL who are currently in remission.

\section{Methods}

Patients and cells. Four patients (L14, L23, L54, and L81) with T-ALL were studied. Ages at diagnosis were 10, 7, 9, and $28 \mathrm{yr}$, respectively. The immunophenotype of these leukemias was CD5 + CD7 + CD19 - TdT + (terminal deoxynucleotidyl transferase). Patients were treated according to Pediatric Oncology Group protocol 8704 (26) (patients L14, L23, and L54) or a minor modification of the Linker regimen for adult ALL (27) (patient L81). Normal peripheral blood mononuclear cells were obtained from consenting adults. Small samples of thymus were obtained from children (ages 1-20 mo) undergoing cardiac surgery. Verterbral bone marrow was obtained at autopsy from young adult accident victims within $12 \mathrm{~h}$ postmortem. T-ALL cell lines RPMI 8402 (28) and MOLT 16 (29) were grown in RPMI 1640 medium containing $10 \%$ fetal bovine serum. Blood and bone marrow leukocytes were lysed with ammonium chloride and high molecular weight DNA purified by standard methods (30).

DNA amplification. PCR were carried out as recommended by the manufacturer (Perkin-Elmer Cetus Corp., Norwalk, CT), except that 1 $\mathrm{U}$ of Perfect Match (Stratagene Inc., San Diego, CA) was included in each reaction. In early experiments, a pair of oligonucleotide primers, C and D, were used to amplify a $t a l^{\mathrm{d}}$ fragment of $\sim 225 \mathrm{bp}(25)$. To increase specificity of amplification, two new amplimers, P1 and P2, were constructed from the nucleotide sequences on either side of the common deletion (Fig. $1 \mathrm{~A}$ ). Relative to the orientation of the tal-1 gene, oligonucleotide $P 1$ begins 76 bases $3^{\prime}$ to oligonucleotide $C$, and oligonucleotide $\mathbf{P} 2$ is displaced 12 bases $3^{\prime}$ to oligonucleotide $\mathrm{D}$. Oligonucleotides $\mathrm{P} 1$ and $\mathrm{P} 2$, amplifying $\mathrm{tal}^{\mathrm{d}}$ fragments of $\sim 165 \mathrm{bp}$, were routinely used for the detection and quantitation assays reported in this study. Another set of oligonucleotides, X1 and X2, was prepared for the detection of the $\mathrm{tal}^{l}$ translocation in leukemia L23 (Fig. 2). These oligomers amplify a 251-bp fragment from the L23 leukemia. High molecular weight DNA (0.1-10 $\mu \mathrm{g})$ was added to PCR mixtures and the corresponding number of genome copies was calculated assuming that $1.5 \times 10^{5}$ diploid cells contain $1 \mu \mathrm{g}$ DNA. Amplification was accomplished in a Perkin-Elmer Cetus Corp. thermal cycler in 60 cycles. The first cycle consisted of $3 \min$ at $94^{\circ}, 1 \mathrm{~min}$ at $61^{\circ}$ and $2 \min$ at $72^{\circ}$; in subsequent cycles the melting step lasted $1 \mathrm{~min}$. Control PCR mixtures were run with every experiment and included normal liver or thymus DNA and $\sim 1 \mathrm{ng}$ tal $^{\mathrm{d}}$ DNA. Oligonucleotides P1 and F (Fig. 1 $A$ ) were used to confirm the integrity of the DNA samples; all samples contain at least one normal germline chromosome $1 \mathrm{p}$, which yields a 250-bp fragment upon PCR containing these primers. Standard precautions were taken to avoid contamination of PCR reaction mixtures with PCR products (31).

Hybridization. Aliquots of the PCR mixtures were separated on 3\% NuSeive/1\% SeaKem GTG agarose gels (FMC Bioproducts, Rockland, $\mathrm{ME}$ ), denatured, transferred to Hybond-N filters (Amersham Corp., Arlington Heights, IL) and fixed to the filter by baking. Two kinds of oligonucleotides were used for hybridization. The first, oligonucleotide $\mathrm{H}$, was an 18-mer which detected all $\mathrm{tal}^{\mathrm{d}}$ alleles (Fig. $1 \mathrm{~A}$ ). The second were 4 oligonucleotides which detected specific rearrangements in the $\mathrm{tal}^{\mathrm{d}}$ leukemias L14, L54 and L81 (Fig. $1 \mathrm{~B}$ ) or the $\mathrm{tal}^{\mathrm{t}}$ leukemia L23 (oligonucleotide H2; Fig. 2). End labeling of oligonucleotides, hybridization and stringent washing was carried out as previously described (32).

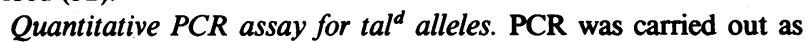
described above, except that internal standard DNAs were added to each reaction $(33,34)$. The standards were chosen to yield an amplified product that differed in size from the target product by $\sim 10 \mathrm{bp}$. Thus, RPMI 8402 DNA was used as a standard in assays for L14 alleles, while MOLT-16 DNA was used in assays for L54 alleles (Fig. 1 B). DNA standards were serially diluted into normal liver or thymus DNA (12

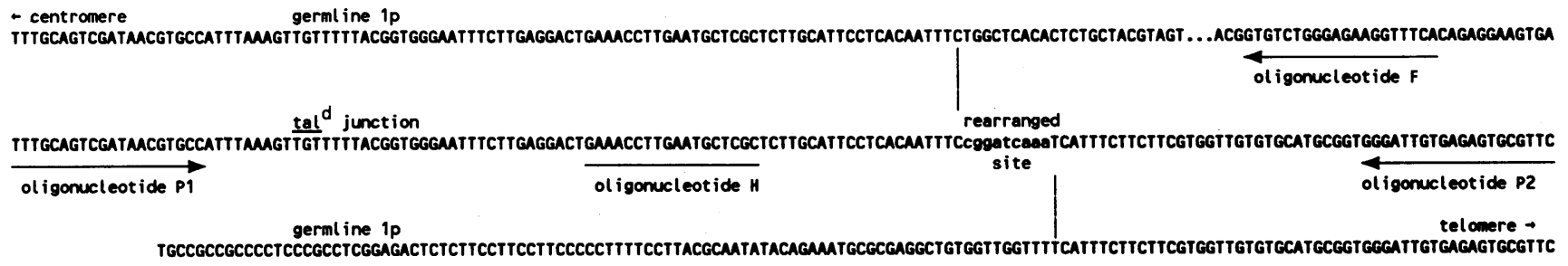

germline centromeric ip CATTCCTCACAATTTCTGGCTCACACTCTGCTACGTAGTAAGGG

$\begin{array}{ll}\text { Cell line } & \text { RPMI } 8402 \\ & \text { MOLT } 16 \\ \text { Patient } & \text { L14 } \\ & \text { L54 } \\ & \text { L81 }\end{array}$

germline telomeric 1p

CATTCCTCACAATTTC
CATTCCTCACAATTCTGGCTCTA
CATTCCTCACAATTCTGG
CATTCCTCACAATTCTGGC
CATTCCTCACAATTTTGG

\section{cggatcaaa \\ ttaggggttc \\ gaaacgactt}

g

TCATTTCTTC
GGTTTPCATTTCTTC
TTGGTTTTCATTTCTTC
GTTGGTTTTCATTTCTTC
GGTTTTCATTTCTTC

$159 \mathrm{bp}$

$172 \mathrm{bp}$

$170 \mathrm{bp}$

$162 \mathrm{bp}$

$159 \mathrm{bp}$

Figure 1. $(A)$ Sequence of the deleted $t a l-1\left(t a l^{d}\right)$ allele derived from the cultured T-ALL cell line RPMI 8402. The germline sequences of the centromeric (top line) and telomeric (bottom line) sides of the rearrangement are aligned with the tal ${ }^{\mathrm{d}}$ allele (middle line). About $90 \mathrm{~kb}$ of the normal sequence is deleted due to the rearrangement (reference 25). The distal end of this deletion lies in the first intron of the tal-1 gene. Junctional nucleotides not found in the germline sequences are in lower case letters. Oligonucleotides P1 and P2 are used to amplify $t a l^{\mathrm{d}}$ alleles. Oligonucleotides P1 and F amplify a 250-bp fragment on the $5^{\prime}$ (centromeric) side of normal tal-1 alleles and serve as control primers in PCR assays. Oligonucleotide $\mathrm{H}$ is used to detect amplified $t a l^{\mathrm{d}}$ alleles in hybridization assays. Dots $(\cdots)$ in the top line signify nucleotides omitted from the figure. (B) tal $^{\mathrm{d}}$ alleles from five T-ALLs, including three patients currently in remission (L14, L54, L81) and two cell lines (RPMI 8402 and MOLT 16). As in $A$, the $t a l^{\mathrm{d}}$ sequences are aligned with germline centromeric (top line) and telomeric (bottom line) sequences, and nongermline nucleotides are shown in lower case letters. The sizes of fragments amplified with oligonucleotides P1 and P2 are shown at the right. 


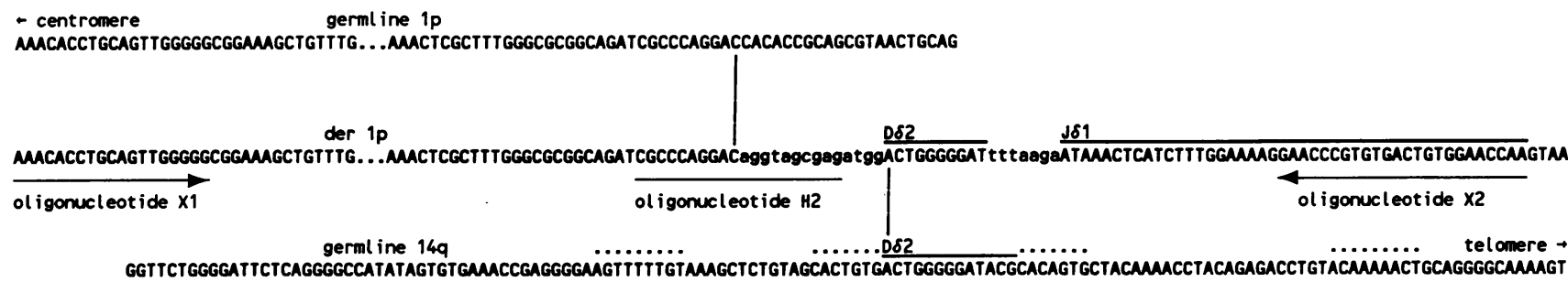

Figure 2. Sequence of the translocated tal-1 (tal ${ }^{l}$ ) allele in T-ALL from patient L-23. Chromosome $1 \mathrm{p}$ (top line) and 14q (bottom line) sequences are aligned with the tal' allele (middle line). The breakpoint on chromosome $1 \mathrm{p}$ is in the first known intron of the tal-1 gene, $2.5 \mathrm{~kb} 3^{\prime}$ of the distal side of the $t a l^{d}$ rearrangements (references 16 and 17). The translocation creates a der $1 \mathrm{p}$ chromosome, which joins the first exon of the tal-1 gene to a rearranged D $\delta 2-\mathrm{J} \delta 1$ gene on chromosome $14 \mathrm{q} 11$. Nongermline junctional nucleotides are shown in lower case letters. D $\delta 2$ and $\mathrm{J} \delta 1$ segments are overlined. Heptamer-nonamer recombination sequences surrounding the germline $\mathrm{D} \delta 2$ segment are highlighted with overlying

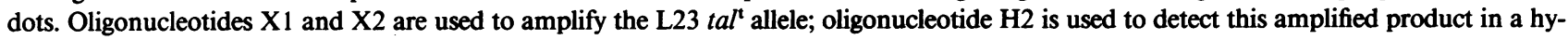
bridization assay. Dots $(\cdots)$ in the top and middle lines signify nucleotides omitted from the figure.

$\mu \mathrm{g} / \mathrm{ml})$. The dilutions of standard DNA were added to PCR mixtures containing target DNAs whose $t l^{\mathrm{d}}$ alleles were to be quantitated. The products were separated by electrophoresis through $10 \%$ polyacrylamide gels and visualized by staining with ethidium bromide. The original number of target $t a l^{\mathrm{d}}$ alleles was estimated by densitometric comparison of staining intensities of the standard and target products. Equal numbers of standard and target alleles present at the start of amplification were shown to generate equal yields of products. Refined estimates of target allele number were obtained by repeating assays in the presence of a narrow range of twofold dilutions of standard DNAs.

\section{Results}

Basis for detection of tal-1 gene rearrangements in $T-A L L$. The rearrangements of the tal-1 gene exploited in this study are shown in Figs. 1 and 2. The $t_{a l}^{\mathrm{d}}$ alleles are the consequence of an $\sim 90 \mathrm{~kb}$ deletion which amputates at least one exon of the tal-1 gene on chromosome $1 \mathrm{p} \mathrm{(25).} \mathrm{The} 5^{\prime}$ and $3^{\prime}$ ends of these deletions are remarkably clustered within a few base pairs in all $t a l^{\mathrm{d}}$ alleles sequenced so far (25). For the five T-ALLs studied herein, the sequences near these ends are shown in Figure $1 B$. Each $t a l^{\mathrm{d}}$ allele differs by several nucleotides at the proximal and distal ends of the deletion and in the sequence of the extra nongermline nucleotides that replace the deletion. These features enable the specific detection of these alleles by PCR and hybridization assays, as described in Methods. A similar strategy was used to detect the $t(1 ; 14)(\mathrm{p} 32 ; \mathrm{q} 11)\left(\mathrm{tal}^{\mathrm{t}}\right)$ allele in material from patient L23 (Fig. 2).

Distribution of tal ${ }^{d}$ alleles. Using Southern hybridization analysis, we previously reported that the $t^{\text {d }}$ rearrangement was found in 13 of $50 \mathrm{~T}$-ALL diagnostic blood or bone marrow samples (25). In this study, we found a perfect correlation between results of the Southern and PCR assays of these 50 leukemias. A sample of the data is shown in Fig. 3. In Southern hybridization to a tal-1 probe, two tal $^{\mathrm{d}}$-positive leukemias (lanes 4 and 8 ) yielded a novel 4.5-kb EcoRI fragment. PCR assays containing oligonucleotides $\mathrm{C}$ and $\mathrm{D}$ generated products $\sim 225 \mathrm{bp}$ in length from the same two leukemias (see Methods) (25). The other seven leukemias shown in Fig. 3 were negative by both Southern and PCR analysis.

In order for the $t a l^{\mathrm{d}}$ PCR assay to be a useful tool for the detection of minimal residual disease, tal $^{\mathrm{d}}$-bearing cells should not be found in normal hematopoietic tissues. Using the PCR assay, we found no evidence of such cells in normal peripheral blood mononuclear cells $(n=40)$, thymus $(n=5)$, or bone marrow $(n=5)$ (data not shown). The sensitivity of this assay was 5-10 genome copies (cells) per $10^{6}$. Therefore, within the limits of detection of this assay, tal $^{\mathrm{d}}$ rearrangements are specific for leukemic cells.

Detection of residual disease in $T$ - $A L L$. Four patients with T-ALL were studied. Three of these leukemias (L14, L54, and L81) contained the tal $^{\text {d }}$ deletion, while the fourth (L23) had the $\mathrm{tal}^{t}$ translocation. The results of surveillance for $\mathrm{tal}^{\mathrm{d}}$ alleles are shown in Fig. 4 and summarized in Table I. All four patients were in complete remission at the time of collection of the samples for assay.

Characteristic bands representing $\mathrm{tal}^{\mathrm{d}}$ fragments were amplified in PCRs containing the diagnostic bone marrow samples from each of these three patients (Fig. 4, lanes 1, 6, and 10). These bands differ slightly in size, as predicted from the sequences of the corresponding $\mathrm{tal}^{\mathrm{d}}$ alleles (Fig. $1 \mathrm{~B}$ ). Oligonucleotide probes $\mathrm{H}$ and $\mathrm{P} 1$, but not $\mathrm{P} 2$, hybridized to faster-migrating bands as well (Fig. $4 C$, lanes 1, 3, 4, and 7; and data not shown). Therefore, these faster-migrating bands are probably single-stranded $t_{a l}{ }^{\mathrm{d}}$ DNA produced during the PCR reaction (35). Dilution experiments demonstrated a sensitivity of detection of 10 copies per $10^{6}$ (Fig. $4 A$ and $C$, lanes $2-4$ ). tal ${ }^{\mathrm{d}}$ alleles were not detected in blood or bone marrow samples drawn from patients L14 and L81 between the 4th and 20th mo of

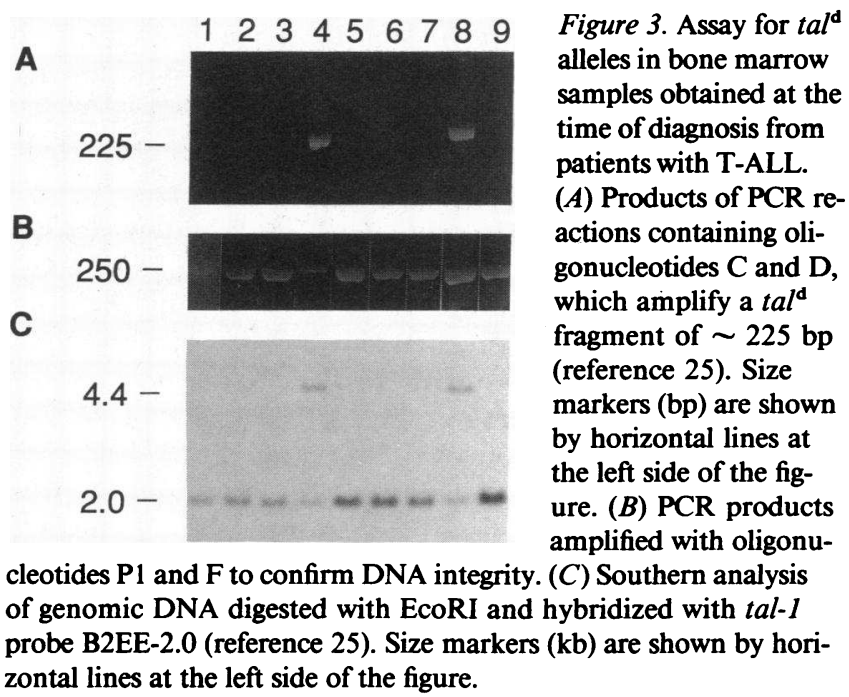




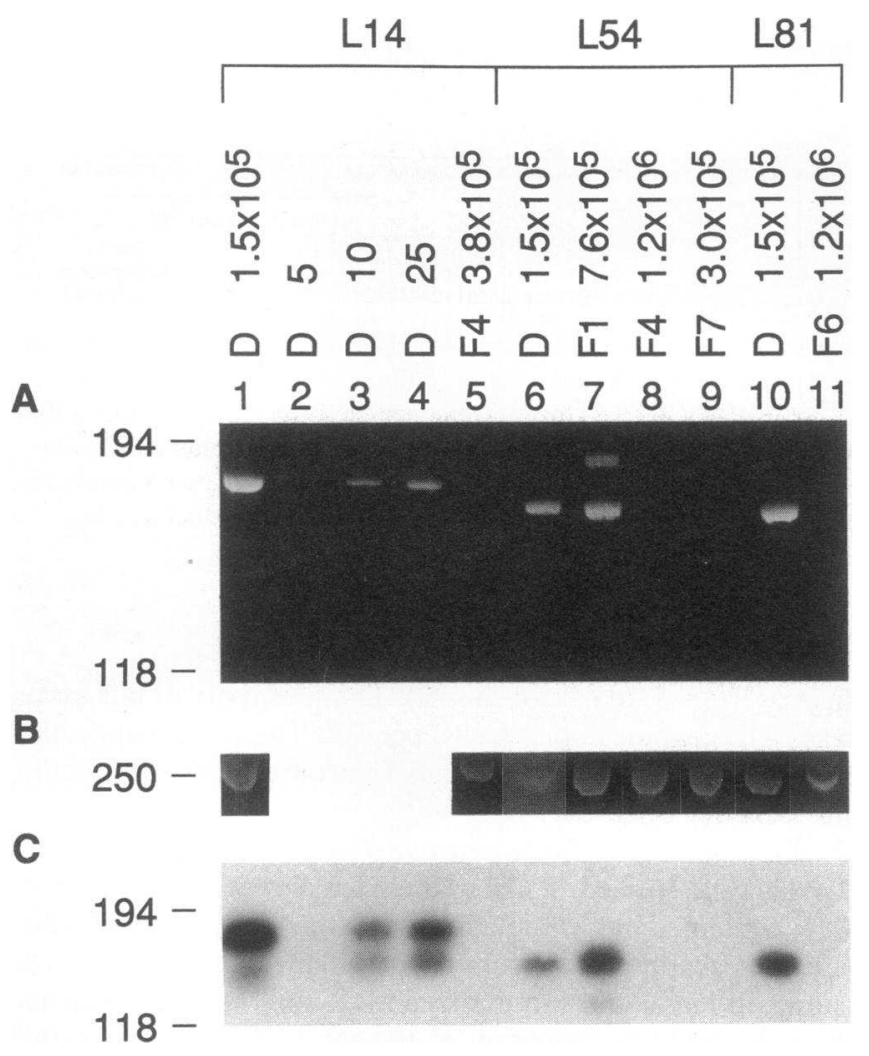

Figure 4. Detection of $t a l^{\mathrm{d}}$ alleles by amplification/hybridization assay. PCR mixtures contained: high molecular weight DNA derived from blood or bone marrow cells of patients $\mathrm{L} 14, \mathrm{~L} 54$, or L81; and either $(A$ and $C$ ) oligonucleotides $\mathrm{P} 1$ and $\mathrm{P} 2$ (Fig. $1 A$ ) for detection of $t a l^{\mathrm{d}}$ alleles; or $(B)$ oligonucleotides $\mathrm{P} 1$ and $\mathrm{F}$ (Fig. $1 A$ ) to control for DNA integrity. $D$ indicates diagnostic sample; $F$ samples are follow-up peripheral blood leukocytes collected during clinical remission (Table I). The number of genome copies added to PCR mixtures, shown above the lanes, was calculated assuming $1 \mu \mathrm{g} D N A=1.5$ $\times 10^{5}$ genomes. Size markers $(\mathrm{bp})$ are shown by horizontal lines on the left side of the figure. $(A$ and $B$ ) Ethidium bromide-stained $10 \%$ polyacrylamide gels of $\mathrm{PCR}$ products. $(C)$ Southern hybridization of PCR products amplified with oligonucleotides $\mathrm{P} 1$ and $\mathrm{P} 2$, probed with oligonucleotide $\mathrm{H}$ (Fig. $1 \mathrm{~A}$ ).

treatment (Table I). Examples of these negative assays are shown in Fig. 4, lanes 5 and 11 . By contrast, tal alleles were detected in a blood sample drawn from patient L54 during the 4th mo of therapy (Fig. 4, lane 7). However, specimens collected from patient L54 from the 5th through the 11 th mo of treatment were negative (Table I).

Detection of $t a l^{\mathrm{t}}$ alleles in material from patient L23 is shown in Fig. 5 and Table I. The characteristic 251-bp band was seen upon amplification of DNA isolated from the diagnostic marrow sample (Fig. $5 A$, lane 1 ). This band was not obtained with normal thymus DNA (lane 5) and was distinct from the control 250-bp fragment from the $5^{\prime}$ region of the tal-1 locus amplified with oligonucleotides $P 1$ and $F(B)$. The sensitivity of detection, 5-10 copies per $10^{6}$, was similar to that obtained in the tal $^{\text {d }}$ assay (lanes 2-4). A blood sample drawn in the 19 th mo of therapy was negative (lane 6). However, 1 mo later the assay was clearly positive (lane 7). Because this patient showed no clinical or hematological signs of relapse at the time the latter sample was collected, this assay result implies the appearance of a minimal tumor burden rather late in the course of treatment of patient L23. Further observation is necessary to understand the significance of this finding.

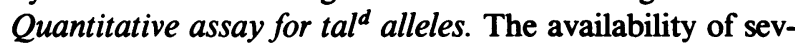
eral $\mathrm{tal}^{\mathrm{d}}$ alleles, each of which yielded a PCR product of distinct size, allowed us to establish a quantitative assay for genomes containing these rearrangements. In this assay, known amounts of a $\mathrm{tal}^{\mathrm{d}}$-containing genomic DNA served as internal standards for the measurement of target alleles $(33,34)$. Standard and target PCR products were distinguished by their different lengths on polyacrylamide gels. The ratio of the yields of the two products was estimated by visual inspection and scanning densitometry. As shown in Figure $6 A$, this assay accurately measured 50 and 250 copies of L14D tal $^{\mathrm{d}}$ alleles diluted into $1.2 \times 10^{6}$ normal thymus genome copies. In this case, the RPMI $8402 \mathrm{tal}^{\mathrm{d}}$ allele served as the internal standard for the L14D target allele, the PCR products differing by $11 \mathrm{bp}$ in length (Fig. $1 \mathrm{~B}$ ). To measure the number of $\mathrm{tal}^{\mathrm{d}}$ alleles in blood sample L54F1, MOLT 16 DNA was chosen as a standard. Approximately 30 copies of the L54 allele per $1.9 \times 10^{5}$ genomes $\left(150 / 10^{6}\right)$ were present at this time point (Fig. 6 B). As noted, samples obtained from patient L54 after this time were negative in the amplification/hybridization assay and therefore contained $<10 \mathrm{tal}^{\mathrm{d}}$ alleles per sample analyzed (Fig. 4, Table I).

Table I. Rearranged tal-1 Alleles in Blood and Bone Marrow Samples from T-ALL Patients

\begin{tabular}{|c|c|c|c|}
\hline Patient & Sample & $\begin{array}{l}\text { Month of } \\
\text { treatment }\end{array}$ & Detection \\
\hline \multirow[t]{5}{*}{ L14* } & $D^{\S}$ & 1 & + \\
\hline & F1 & 4 & - \\
\hline & F2 & 17 & - \\
\hline & F3 & 18 & - \\
\hline & F4 & 20 & - \\
\hline \multirow{9}{*}{ L54* } & D & 1 & + \\
\hline & F1 & 4 & $+\left(150 / 10^{6}\right)$ \\
\hline & F2 & 5 & - \\
\hline & F3 & 6 & - \\
\hline & F4 & 8 & - \\
\hline & F5 & 9 & - \\
\hline & F6 & 9 & - \\
\hline & $F 7^{8}$ & 10 & - \\
\hline & F8 & 11 & - \\
\hline \multirow[t]{4}{*}{ L81* } & D & 1 & + \\
\hline & F3 & 13 & - \\
\hline & F4 & 14 & - \\
\hline & F6 & 15 & - \\
\hline \multirow[t]{3}{*}{$\mathrm{L}^{2} 3^{\ddagger}$} & D & 1 & + \\
\hline & F2 & 19 & - \\
\hline & F3 & 20 & + \\
\hline
\end{tabular}

DNA was extracted from diagnostic $(D)$ or follow-up $(F)$ peripheral blood or bone marrows leukocytes and assayed by the amplification/hybridization procedure for $\operatorname{tal}^{\mathrm{d}}\left(^{*}\right)$ or $t a l^{\mathbf{t}}\left(^{(}\right)$alleles. + , alleles detected; - , alleles not detected. Both blood and bone marrow from patient L54 were assayed at month 10 . tal ${ }^{\mathrm{d}}$ alleles in sample L54F1 were quantitated as described in Methods. 


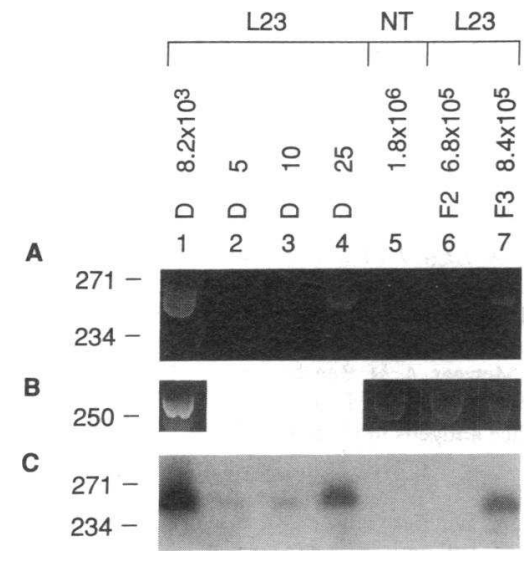

Figure 5. Detection of tal $^{t}$ alleles by amplification/hybridization assay. PCR mixtures contained: high molecular weight DNA derived from blood or bone marrow cells of patient L23; and either ( $A$ and $C$ ) oligonucleotides $\mathrm{X} 1$ and X2 (Fig. 2) for detection of al $^{\prime}$ alleles; or (B) oligonucleotides P1 and $\mathrm{F}$ (Fig. $1 A$ ) to control for DNA integrity. $D$ indicates diagnostic

sample; $F$ samples are follow-up peripheral blood leukocytes collected during clinical remission (Table I). $N T$ indicates normal thymus DNA. The number of genome copies added to PCR mixtures, shown above the lanes, was calculated assuming $1 \mu \mathrm{g}$ DNA $=1.5 \times 10^{5}$ genomes. $(A$ and $B)$ Ethidium bromide-stained $10 \%$ polyacrylamide gel of PCR products. $(C)$ Southern hybridization of PCR products amplified with oligonucleotides $\mathrm{X} 1$ and $\mathrm{X} 2$, probed with oligonucleotide $\mathrm{H} 2$ (Fig. 2).

\section{Discussion}

Although significant improvements in long term disease-free survival have resulted from contemporary therapeutic programs, $\sim 40 \%$ of children and $60 \%$ of adults with T-ALL still relapse and die of drug-resistant leukemia. At the same time, an increasing variety of therapeutic modalities has appeared, including novel doses and schedules of existing drugs, newer agents such as pentostatin (deoxycoformycin), biologic response modifiers such as $\alpha$-interferon, immunotoxins, and allogeneic or autologous bone marrow transplantation. Because the total pool of patients is relatively small and prognostic stratification is not well developed, progress in selection of optimal therapy for individual patients has been limited. Accurate detection and quantitation of disease during the intensive postinduction phase of therapy could facilitate selection of the best consolidation/maintenance approach for each individual patient.

Site-specific DNA rearrangements in ALL cells provide clonal markers for the detection of residual disease. These rearrangements are of two sorts: physiologic immune receptor gene rearrangements and pathologic recombinational events such as chromosomal translocations, deletions, and insertions. Examples of the former process are TCR $\delta$ VDJ segment rearrangements which have been exploited as clonal markers for T-ALL populations $(36,37)$. Potential disadvantages of this approach include the requirement for specific probes for each clone, the dominance of new rearrangements during clonal progression, and doubts regarding true tumor specificity of the particular rearrangement being monitored. Use of the latter, pathological kinds of rearrangements as clonal markers may overcome these limitations, especially if a site-specific abnormality were found in a large fraction of T-ALLs.

The $t(1 ; 14)(p 34 ; q 11)$ translocation is found in only $3 \%$ of T-ALL (24). The finding of a gene tal-1, encoding a candidate helix-loop-helix DNA binding protein at the site of the breakpoints on chromosome $1 \mathrm{p}$, raised the question whether other, nontranslocational rearrangements of this gene might be involved in leukemias of this type. Remarkably, 13 of 50 such leukemias were found to contain nearly identical deletions of $\sim 90 \mathrm{~kb}$ from the upstream region of this gene (25). The deletions were not found in remission peripheral blood leukocytes, indicating that $t a l^{\mathrm{d}}$ alleles are not germline genetic polymorphisms in these patients (25). The site of this common rearrangement within the first known intron of the tal-1 locus is $\sim 1 \mathrm{~kb} 5^{\prime}$ of a cluster of breakpoints found in the $t(1 ; 14)(p 34 ; q 11)$ translocations in T-ALL (25). In addition to adding strong circumstantial evidence for a role of these tal-1 rearrangements in the pathogenesis of T-ALL, the remarkably focused nature of the rearrangements provides an opportunity to monitor the leukemic clones with straightforward genomic PCR assays. A single pair of amplimers sufficed for all $t a l^{\mathbf{d}}$ alleles, while a few additional pairs should be adequate to detect the tal $^{t}$ cases. A total of $\sim 30 \%$ of T-ALLs should thus be amenable to disease monitoring based upon these tal-1 rearrangements.

The success of this approach depends upon the absence of tal-1 rearrangements in normal hematopoietic cells. The sitespecific nature of these rearrangements raises the question whether they could play a role in normal $\mathrm{T}$ cell development or function. Moreover, aberrant trans-rearrangements involving immune receptor genes have been demonstrated by PCR of normal thymocyte DNA (38). Since both kinds of tal-1 rearrangements studied herein may originate from misdirected ac-

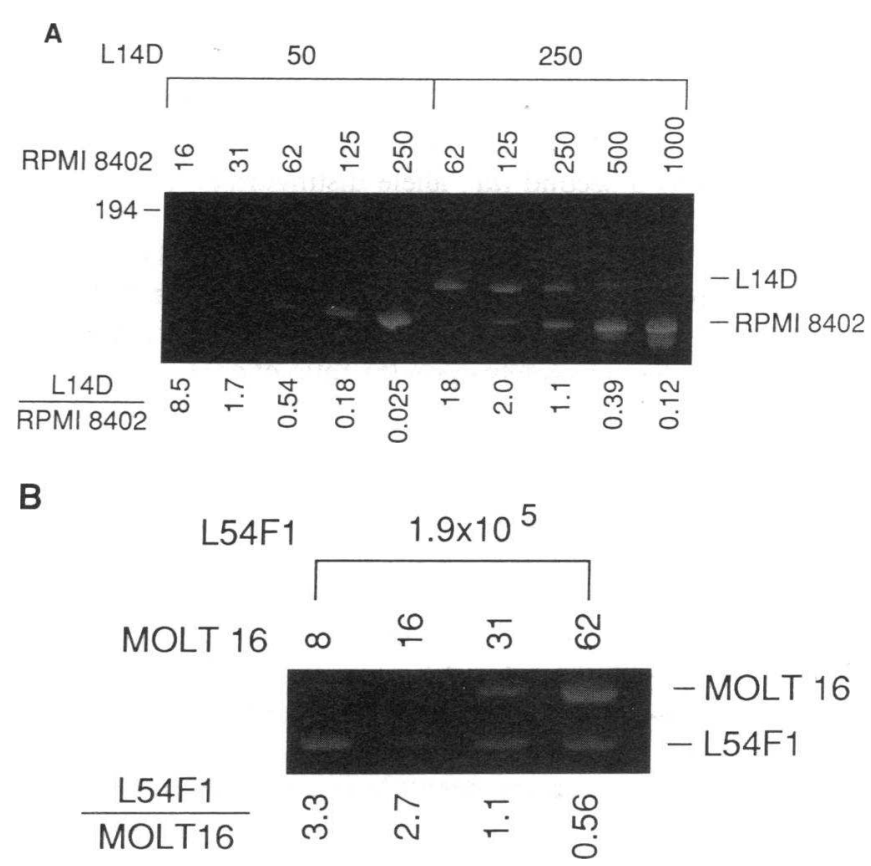

Figure 6. Quantitation of tal $^{\text {d }}$ alleles using an internal standard in PCR assay. $(A)$ Quantitation of L14D tal ${ }^{d}$ alleles. Varying amounts of RPMI 8402 DNA, shown as genome copies above the lanes, were added to PCR mixtures containing either 50 or 250 genome copies of L14D DNA. The products were analyzed on a $10 \%$ polyacrylamide gel and stained with ethidium bromide. The L14D and RPMI 8402 products are marked on the right side of the figure; a size marker $(194 \mathrm{bp})$ is shown on the left. The band intensities were quantitated densitometrically and the ratios of these intensities are shown below the lanes. (B) Quantitation of L54F1 tal ${ }^{d}$ alleles. Varying amounts of MOLT 16 DNA were added to PCR mixtures containing $1.9 \times 10^{5}$ genome copies of L54F1 DNA. The results are displayed as described in $A$. 
tion of the immune receptor recombinase, we examined cell populations containing mature and developing $T$ lymphocytes for evidence of $t a l^{d}$ alleles. Using the amplification/hybridization assay, which detects 10 rearranged alleles among $10^{6}$ cells, we did not detect any tal $^{\mathbf{d}}$ alleles in normal mature or differentiating hematopoietic tissues. Thus, it is unlikely that rearrangements at the tal-1 locus play any important developmental or functional role in normal $\mathrm{T}$ cells. Of practical significance, the low background of these rearrangements in normal hematopoietic cells should not interfere with sensitive and specific detection of the leukemic clones.

In this study, we have tested in four patients the suitability of tal-1 gene rearrangements as clonal markers for T-ALL. Of the three subjects with tal $^{\mathrm{d}}$ leukemia, evidence of residual disease was found early in remission in one (L54). However, the leukemic $t^{\mathrm{d}} \mathrm{l}^{\mathrm{d}}$ marker was not detected during an ensuing follow-up period of $7 \mathrm{mo}$. On the other hand, the one patient with $t(1 ; 14)(\mathrm{p} 32 ; \mathrm{q} 11)\left(\mathrm{tal}^{\mathrm{t}}\right)$ disease had a positive PCR assay in his 20 th mo of treatment which was preceeded by a negative assay. Only further observation of these and other patients will test the predictive power of these assays for disease recurrence.

Previous experience suggests that the ability to quantitate these alleles in serial samples should increase the reliability of relapse prediction. For example, in patients with chronic myelogenous leukemia followed after marrow ablation and allogeneic bone marrow transplantation, the finding of isolated $\mathbf{P h}^{\prime}$ translocations either by cytogenetic or PCR assay has not predicted subsequent relapse. On the other hand, serial increases in the $\mathrm{Ph}^{\prime}$ marker or its molecular equivalent have correlated with hematologic relapse $(11-15,39)$. Therefore, we sought to develop a quantitative assay for $t^{\mathrm{d}}{ }^{\mathrm{d}}$ alleles based on the PCR method. The modified assay relies on an internal standard which contains a second $t_{a l}{ }^{d}$ allele distinguishable from the first based on the size of the amplified product. The reliability of this assay depends on the assumption that amplification of these two closely related sequences is equally efficient throughout the PCR. Under these conditions, the relative yield of the two products depends solely upon the ratio of copies present at the start of the reaction $(33,34)$. This assumption should be true if no cis-acting factors favor the amplification of one allele over the other. To ensure such equality, we used only rigorously purified DNA samples in this assay. Under these conditions, the quantitative assay accurately measured 50 to 250 copies of $\mathrm{tal}^{\mathrm{d}}$ alleles present in a large excess of normal DNA. 30 copies $\left(150 / 10^{6}\right)$ of the L54 tal ${ }^{\text {d }}$ allele were found in the L54F1 sample during the 4th mo of treatment. We are currently adapting this approach to the detection of $\mathrm{tal}^{\mathrm{t}}$ as well as $t^{\mathrm{d}}{ }^{\mathrm{a}}$ alleles.

Now that $t a l-1$ rearrangements have been shown to be feasible clonal markers for a large subset of T-ALLs, expanded clinical trials are appropriate to test the accuracy of relapse prediction. One ancillary question to be addressed in such trials is the stability of these rearrangements as clonal markers during disease progression. A small subset of T-ALL patients relapse with or develop de novo myeloid leukemia (40). Whether tal-1 rearrangements persist during such shifts in phenotype is an intriguing issue touching on both the biology and management of these lineage-switching leukemias.

\section{Acknowledgments}

We thank Jayne Cash for blood samples from patients L14, L23, and L54, Barry Cooper for blood samples and clinical data from patient L81, and Eugene Frenkel for a critical reading of the manuscript.
This work was supported by the National Cancer Institute (grants CA-42891, CA-44016, CA-46593, CA-47975, CA-33625, and CA21675 [Core]), the Children's Cancer Fund of Dallas, the Weekend to Wipe Out Cancer, and the Nasher Family Cancer Research Fund.

\section{References}

1. Sen, L., and L. Borella. 1975. Clinical importance of lymphoblasts with T-markers in childhood leukemia. N. Engl. J. Med. 292:828-832.

2. Tsukimoto, I., K. Y. Wong, and B. C. Lampkin. 1976. Surface markers and prognostic factors in acute lymphoblastic leukemia. N. Engl. J. Med. 294:245248.

3. Roper, M., W. M. Crist, R. Metzgar, A. H. Ragab, S. Smith, K. Starling, J. Pullen, B. Leventhal, A. A. Bartolucci, and M. D. Cooper. 1983. Monoclonal antibody characterization of surface antigens in childhood T-cell lymphoid malignancies. Blood. 61:830-837.

4. Shuster, J. J., J. M. Falletta, D. J. Pullen, W. M. Crist, G. B. Humphrey, B. L. Dowell, M. D. Wharam, and M. Borowitz. 1990. Prognostic factors in childhood T-cell acute lymphoblastic leukemia: a pediatric oncology group study. Blood. 75:166-173.

5. Pui, C. H., F. G. Behm, B. Singh, M. J. Schell, D. L. Williams, G. K. Rivera D. K. Kalwinsky, J. T. Sandlund, W. M. Crist, and S. C. Raimondi. 1990. Heterogeneity of presenting features and their relation to treatment outcome in 120 children with T-cell acute lymphoblastic leukemia. Blood. 75:174-179.

6. Hoelzer, D., E. Thiel, H. Löffler, T. Büchner, A. Ganser, G. Heil, P. Koch, M. Freund, H. Diedrich, H. Ruhl, et al. 1988. Prognostic factors in a multicenter study for treatment of acute lymphoblastic leukemia in adults. Blood. 71:123131.

7. Gaynor, J., D. Chapman, C. Little, S. McKenzie, W. Miller, M. Andreeff, Z. Arlin, E. Berman, S. Kempin, T. Gee, and B. Clarkson. 1988. A cause-specific hazard rate analysis of prognostic factors among 199 adults with acute lymphoblastic leukemia: the memorial hospital experience since 1969. J. Clin. Oncol. 6:1014-1030.

8. Raimondi, S. C., F. G. Behm, P. K. Roberson, C. H. Pui, G. K. Rivera, S. B. Murphy, and D. L. Williams. 1988. Cytogenetics of childhood T-cell leukemia. Blood. 72:1560-1566.

9. Kaneko, Y., G. Frizzera, T. Shikano, H. Kobayashi, N. Maseki, and M. Sakurai. 1989. Chromosomal and immunophenotypic patterns in $T$ cell acute lymphoblastic leukemia (T-ALL) and lymphoblastic lymphoma (LBL). Leukemia. 3:886-892.

10. Ucken, F. M., K. J. Gajl-Peczalska, A. J. Provisor, and N. A. Heerema 1989. Immunophenotype-karyotype associations in human acute lymphoblastic leukemia. Blood. 73:271-280.

11. Gabert, J., I. Thuret, M. Lafage, Y. Carcassonne, D. Maraninchi, and P. Mannoni. 1989. Detection of residual bcr/abl translocation by polymerase chain reaction in chronic myeloid leukaemia patients after bone-marrow transplantation. Lancet. ii:1125-1128.

12. Lange, W., D. S. Snyder, R. Castro, J. J. Rossi, and K. G. Blume. 1989. Detection by enzymatic amplification of bcr-abl mRNA in peripheral blood and bone marrow cells of patients with chronic myelogenous leukemia. Blood. 73:1735-1741.

13. Delfau, M. H., J. P. Kerckaert, M. Collyn d'Hooghe, P. Fenaux, J. L. Laï, J. P. Jouet, and B. Grandchamp. 1990. Detection of minimal residual disease in chronic myeloid leukemia patients after bone marrow transplantation by polymerase chain reaction. Leukemia. 4:1-5.

14. Kohler, S., N. Galili, J. L. Sklar, T. A. Donlon, K. G. Blume, and M. L. Cleary. 1990. Expression of bcr-abl fusion transcripts following bone marrow transplantation for Philadelphia chromosome-positive leukemia. Leukemia. 4:541-547.

15. Sawyers, C. L., L. Timson, E. S. Kawasaki, S. S. Clark, O. N. Witte, and R. Champlin. 1990. Molecular relapse in chronic myelogenous leukemia patients after bone marrow transplantation detected by polymerase chain reaction. Proc. Natl. Acad. Sci. USA 87:563-567.

16. Chen, Q., J.-T. Cheng, L.-H. Tsai, N. Schneider, G. Buchanan, A. Carroll, W. Crist, B. Ozanne, M. Siciliano, and R. Baer. 1990. The tal gene undengoes chromosome translocation in $\mathrm{T}$ cell leukemia and potentially encodes a helixloop-helix protein. EMBO (Eur. Mol. Biol. Organ.) J. 9:415-424.

17. Chen, Q., C. Y.-C. Yang, J. T. Tsan, Y. Xia, A. H. Ragab, S. C. Peiper, A. Carroll, and R. Baer. 1990. Coding sequences of the tal-1 gene are disrupted by chromosome translocation in human T cell leukemia. J. Exp. Med. 172:14031408 .

18. Murre, C., P. S. McCaw, and D. Baltimore. 1989. A new DNA binding and dimerization motif in immunoglobulin enhancer binding, daughterless, MyoD, and myc proteins. Cell. 56:777-783.

19. Leder, P., J. Battey, G. Lenoir, C. Moulding, W. Murphy, H. Potter, T. Stewart, and R. Taub. 1983. Translocations among antibody genes in human cancer. Science (Wash. DC). 222:765-771.

20. Mellentin, J. D., S. D. Smith, and M. L. Cleary. 1989. lyl-1, a novel gene altered by chromosomal translocation in T cell leukemia, codes for a protein with a helix-loop-helix DNA binding motif. Cell. 58:77-83. 
21. Mellentin, J. D., C. Murre, T. A. Donlon, P. S. McCaw, S. D. Smith, A. J. Carroll, M. E. McDonald, D. Baltimore, and M. L. Cleary. 1989. The gene for enhancer binding proteins E12/E47 lies at the $t(1 ; 19)$ breakpoint in acute leukemias. Science (Wash. DC). 246:379-382.

22. Nourse, J., J. D. Mellentin, N. Galili, J. Wilkinson, E. Stanbridge, S. D. Smith, and M. L. Cleary. 1990. Chromosomal translocation $t(1 ; 19)$ results in synthesis of a homeobox fusion mRNA that codes for a potential chimeric transcription factor. Cell. 60:535-545.

23. Kamps, M. P., C. Murre, X. H. Sun, and D. Baltimore. 1990. A new homeobox gene contributes the DNA binding domain of the $t(1 ; 19)$ translocation protein in pre-B ALL. Cell. 60:547-555.

24. Carroll, A., W. Crist, M. P. Link, M. D. Amylon, D. J. Pullen, A. H. Ragab, G. R. Buchanan, R. S. Wimmer, and T. J. Vietti. 1990. The $t(1 ; 14)(p 34 ; q 11)$ translocation is non-random and restricted to $T$-cell acute lymphoblastic leukemia. Blood. 76:1220-1224.

25. Brown, L., J.-T. Cheng, Q. Chen, M. Siciliano, W. Crist, G. Buchanan, and $\mathbf{R}$. Baer 1990. Site-specific recombination of the tal-1 gene is a common occurrence in human T cell leukemia. EMBO (Eur. Mol. Biol. Organ.) J. 9:33433351.

26. Amylon, M., S. Murphy, and J. Pullen. 1988. Treatment of lymphoid malignancies according to immune phenotype: preliminary results in T-cell disease. Proc. Am. Soc. Clin. Oncol. 7:225a. (Abstr.)

27. Linker, C. A., L. J. Levitt, M. O’Donnell, C. A. Ries, M. P. Link, S. J. Forman, and M. J. Farbstein. 1987. Improved results of treatment of adult acute lymphoblastic leukemia. Blood. 69:1242-1248.

28. Minowada, J., and G. E. Moore. 1975. T lymphocyte cell lines derived from patients with acute lymphoblastic leukemia. In Comparative Leukemia Research 1973: Leukemogenesis. Y. Ito and R. Dutcher, editors. University of Tokyo Press, Tokyo. 251-261.

29. Kohno, K., T. Otani, and J. Minowada. 1986. Human T-cell leukemia cell lines (MOLT 16 and MOLT 17): production of IL2-like factor. Proc. Annu. Meet. Jpn. Cancer Assoc. 45:203a. (Abstr.)
30. Herrmann, B. G., and A.-M. Frischauf. 1987. Isolation of genomic DNA. Methods Enzymol. 152:180-183.

31. Kwok, S., and R. Higuchi. 1989. Avoiding false positives with PCR. Nature (Lond.). 339:237-238.

32. Jonsson, O. G., R. L. Kitchens, F. C. Scott, and R. G. Smith. 1990. Detection of minimal residual disease in acute lymphoblastic leukemia using immunoglobulin hypervariable region specific oligonucleotide probes. Blood. 76:2072-2079.

33. Gilliland, G., S. Perrin, K. Blanchard, and H. F. Bunn. 1990. Analysis of cytokine mRNA and DNA: detection and quantitation by competitive polymerase chain reaction. Proc. Natl. Acad. Sci. USA. 87:2725-2729.

34. Sambrook, J., E. F. Fritsch, and T. Maniatis. 1989. Molecular Cloning: A Laboratory Manual. Cold Spring Harbor Laboratory (CSH), Cold Spring Harbor, NY. 14.30-14.33.

35. Gyllensten, U. B and H. A. Erlich 1988. Generation of single-stranded DNA by the polymerase chain reaction and its application to direct sequencing of the HLA-DQA locus. Proc. Natl. Acad. Sci. USA. 85:7652-7656.

36. Hansen-Hagge, T. E., S. Yokota, and C. R. Bartram. 1989. Detection of minimal residual disease in acute lymphoblastic leukemia by in vitro amplification of rearranged T-cell receptor delta chain sequences. Blood. 74:1762-1767.

37. Campana, D., S. Yokota, E. Coustan-Smith, T. E. Hansen-Hagge, G. Janossy, and C. R. Bartram. 1990. The detection of residual acute lymphoblastic leukemia cells with immunologic methods and polymerase chain reaction: a comparative study. Leukemia. 4:609-614.

38. Tycko, B., J. D. Palmer, and J. Sklar. 1989. T cell receptor gene trans rearrangements: chimeric gamma-delta genes in normal lymphoid tissues. Science (Wash. DC). 245:1242-1246.

39. Arthur, C. K., J. F. Apperley, A. P. Guo, F. Rassool, L. M. Gao, and J. M. Goldman. 1988. Cytogenetic events after bone marrow transplantation for chronic myeloid leukemia in chronic phase. Blood. 71:1179-1186.

40. Pui, C. H., F. G. Behm, S. C. Raimondi, R. K. Dodge, S. L. George, G. K Rivera, J. Mirro, Jr., D. K. Kalwinsky, G. V. Dahl, and S. B. Murphy. 1989. Secondary acute myeloid leukemia in children treated for acute lymphoid leukemia. N. Engl. J. Med. 321:136-142. 